\title{
Anders Pontoppidan Thyssen in memoriam
}

\author{
Af Kim Arne Pedersen
}

Ved Anders Pontoppidan Thyssens død falder det mig naturligt at begynde med en personlig erindring. Det var i mine første studieår $i$ 1980'ernes begyndelse, hvor Anders Pontoppidan Thyssen og Christian Thodberg sammen holdt øvelser over udvalgte dele af Grundtvigs forfatterskab - en fremragende introduktion til studiet af Grundtvig, hvis brede indføring i Grundtvigs teologiske og folkelige tanker jeg og andre har kunnet støtte os til siden. De to lærde professorer var langtfra altid enige, og uenigheden var ikke det mindst lærerige for os studenter. De velkvalificerede indlæg fra professorerne animerede til selvstændig tankevirksomhed og kritisk stillingtagen og gav os indsigt $\mathrm{i}$, hvorledes de skiftende tidsaldres Grundtvig-billede er betinget af den skiftende samfundsmæssige og kulturelle virkelighed.

Vores generation af studenter var under indflydelse af den Grundtvig-renæssance, som fulgte på Kaj Thanings videnskabelige arbejde, 68-bevægelsens begejstring for folkelighedsbegrebet og Ebbe Kløvedal Reichs roman Frederik fra 1972. Alle disse tiltag var præget af Grundtvig-receptionen efter Anden Verdenskrig, hvor det var et fælles projekt at løse Grundtvig ud af grundtvigianernes omklamring og lade ham komme til orde gennem forfatterskabet - uden de forvridninger, som den grundtvigske bevægelse havde afstedkommet siden midten af det 19. århundrede. Denne holdning var sædvanligvis kombineret med en opfattelse af, at Grundtvig efter dette nødvendige fortolkningsarbejde ville fremtræde med en aktualitet, der både kom tidens teologi og det danske samfunds nutidige virkelighed i møde, en holdning, der rent sprogligt kom til udtryk i, at man i disse år brugte den nygrundtvigsk farvede betegnelse "grundtvigsk" frem for "grundtvigiansk".

Inspireret heraf fremførte jeg det synspunkt, at grundtvigianerne aldrig havde forstået Grundtvig, og at der måtte skelnes mellem Grundtvig og dem. Anders Pontoppidan Thyssen så på mig - og begyndte så detaljeret at fremlægge de vestjyske forhandlingsprotokoller, hvoraf man kan se, hvor dyb de første grundtvigianske lægfolks forståelse af Grundtvigs tanker var. Samtidig gjorde han omhyggeligt rede for alle de tidsbundne træk, som vanskeliggør en aktualisering af Grundtvigs forfatterskab. I den sammenhæng pegede han på det grundtvigske historiesyns bundethed til tankeformer, der hørte guldaldertiden til, og bestræbte sig således på at lære mig og de 
andre øvelsesdeltagere at arbejde med den nødvendige distance, som hører til videnskabelig virksomhed.

Samtalen fik afgørende betydning for mig. Thyssen lærte mig at se på Grundtvig $i$ et bredt, samfundsmæssigt perspektiv og at se trådene mellem Grundtvig og grundtvigianerne, ja, videre endnu, se på Grundtvig i perspektiv af det moderne, som det bliver til gennem det 18. århundredes oplysning og pietisme og det 19. århundredes nationalisme og vækkelser.

Thyssens forskning kan sammenfattes under formlen kirken i samfundet, eller bedre med hans egen overskrift fra Grundtvig og grundtvigianismen $i$ nyt lys fra 1983, kirke og folk, for det er karakteristisk for ham, at han i flere sammenhænge brugte de grundtvigske begreber kristendom og folkelighed. Med begreberne folk og folkelighed kunne Thyssen signalere, at han betragtede det 19 . århundredes myndiggørelse af almindelige danskere som noget, der bandt vækkelserne sammen med den nationale strømning, der med Grundtvig fik en særlig dansk prægning, der gør det rimeligt at skelne mellem nationalt og nationalistisk eller endnu bedre: gør det oplagt at bruge Grundtvigs eget folkelighedsbegreb til at karakterisere det særlige derved.

Trods Thyssens distance til Grundtvig mærkede jeg $\mathrm{i}$ hans interesse for folkelighedsbegrebet en glød og begejstring, en positiv holdning til Grundtvigs farverige personlighed og forfatterskab, der ikke kunne andet end at smitte, og samtidig med refleksionerne over det grundtvigske historiesyns bundethed til det 19. århundrede fik Thyssen ridset nogle mulige fortolkninger op, nogle tilgange til Grundtvigs historieskrivning, der nåede dybere lag end det tidsbundne og netop angik forholdet mellem kirke og folk, kristendom og samfund. På denne måde kunne man som student komme Thyssen nær og indgå i en dialog, uden at man derfor blev strøget med hårene.

Jeg blev efterhånden klar over, at det var karakteristisk for Pontoppidan Thyssen, at han på denne måde tog et studenterstandpunkt alvorligt ved at argumentere sagligt imod ud fra sin store empiriske viden om Grundtvigs samtid og eftertid. Pontoppidan Thyssen forlangte meget af sine studenter og stipendiater. Der skulle være orden i sagerne, man skulle have læst kilderne omhyggeligt og have gjort det uden at lade sin læsning styre af fortolkerstandpunkter, og man måtte bestræbe sig på ikke at læse egne synspunkter ind i teksterne. Forudforståelsen var nok nødvendig, men selve arbejdet med stoffet skulle for Thyssen afstedkomme den horisontforskydning, der hører sammen med den egentlige forståelse.

Indimellem kunne det være hårdt at gå $\mathrm{i}$ Pontoppidan Thyssens skole. Kravene var høje, Thyssens analytiske intellekt kunne give sig 
udtryk i en knivskarp kritik, der virkede som et nødvendigt, men langt fra behageligt syrebad. Det gjaldt det hele, fra stavemåder til henvisninger, fra sprogets formelle regler over de direkte citaters nødvendighed til kildematerialets anvendelighed, tankens klarhed og analysens stringens. Thyssens bemærkninger kunne være svidende, og sarkasmen glimtede lejlighedsvis frem. Engang imellem syntes man, tæppet blev trukket væk under fødderne på en, og at den selvtillid, som er nødvendig for arbejdets fuldførelse, blev skudt i sænk. Samtidig lærte man at respektere Thyssen. Han var lige skarp, hvad enten han sad over for en lærd og indflydelsesrig kollega eller over for en student. Han stillede ikke større krav til andre end til sig selv, og hans kritik var båret af et lidenskabeligt ønske om at nå frem til så meget af sandheden, som det nu er fortolkeren beskåret. Og selv når diskussionen bevægede sig fra det videnskabelige håndværk og ind $\mathrm{i}$ en egentlig saglig uenighed, mærkede man hans vilje til at lytte, til at give slip på sig selv og indrømme flere fortolkningsmuligheder i teksterne eller i det mindste prøve at forstå, også der hvor han mødte et synspunkt, der var ham fremmed. Selv gav han ikke blot sin omhu videre, men også sin vilje til ikke at acceptere nemme og tilsyneladende overbevisende tolkninger. Historikerens åbenhed over for kildematerialet var hos ham forenet med viljen til at se forbindelser og sammenhænge, som teologiske fordomme indimellem ikke tillod blev bragt frem i lyset. Det gjaldt eksempelvis den almindelige modstilling af grundtvigianisme og pietisme. Thyssen var selvfølgelig ikke blind for forskellene, men han kunne også se lighederne, og man spørger sig selv, om han ikke her var præget af de strømninger, han mødte i sine første barne- og ungdomsår.

Anders Pontoppidan Thyssens barndomshjem var præget af grundtvigianismen og den kristelige studenterbevægelse. Hans far var i årene før og under Første Verdenskrig præst $\mathrm{i}$ den grundtvigske valgmenighed på Bornholm og blev efter en årrække som sognepræst $\mathrm{i}$ Køng og Odense stiftsprovst i Haderslev. Erik Pontoppidan Thyssen var $\mathrm{i}$ stand til at færdes både $\mathrm{i}$ grundtvigske kredse og studenterbevægelsens KFUM-prægede miljø og bygge bro imellem dem, og når Anders Pontoppidan Thyssen senere bestræbte sig på at knytte kontakter til grundtvigianere såvel som Indre Mission i forskning, blandt studenterne og i kirkelivet, kan det ses som en videreførelse af faderens virke. Moderen, Ellen Friderikson, var finlandssvensk og havde mødt Erik Pontoppidan Thyssen på et kristeligt studentermøde i Finland. Hun blev efter sigende aldrig begejstret for Grundtvig, og sammen med faderens formidlende indsats har det formodentlig været med til at skabe en frugtbar spænding - og et vidsyn - hos Anders 
Pontoppidan Thyssen, der senere skulle berige hans forskning og sætte sig spor i beskæftigelsen med pietismen og dens indflydelse på de gudelige vækkelser samt $i$ en skærpet bevidsthed om de fællestræk, der er mellem denne og Grundtvig selv - alt det, som det var vanskeligt at se i efterkrigstidens tidehvervsk prægede miljø.

Samtidig var der her tale om Anders Pontoppidan Thyssens eget selvopgør. Han var ung i de år, hvor tidehvervsgrundtvigianismen brød frem, og han var levende optaget af sin tid og dens teologi, så levende, at når han siden hen talte imod den tidehvervsk inspirede Grundtvigreception, var det præget af hans egen dybe indlevelse i modstanderens synspunkter - en indlevelse, der kom af, at de havde været hans egne. Thyssens første tekster står trykt i den grundtvigske studenterkreds's tidsskrift, og hans arbejdsliv begyndte også i den praktiske grundtvigske virkelighed. Allerede under studiet ved Københavns Universitet blev Thyssen lærer på Rønshoved Højskole, som Hans Haarder netop da havde købt af Aage Møller. Der er stadig gamle Rønshoved-elever, der kan fortælle om hans undervisning. Thyssen var en afholdt lærer, selv om eleverne ind imellem morede sig over den lærde teologs lidt distræte omgang med praktiske sager.

Thyssen ønskede imidlertid at komme videre med en videnskabelig karriere, og han modtog i 1950 guldmedalje på det nye teologiske fakultet i Aarhus for afhandlingen Valdemar Brückers Stilling indenfor den grundtvigske Kreds indtil ca. 1900, hvoraf dele først blev trykt i samleværket Grundtvig og den grundtvigske arv, som elever og venner udgav $\mathrm{i}$ forbindelse med hans halvfjerds års dag $\mathrm{i}$ 1991. Ved siden af prisopgaven skrev Thyssen en sammenfatning $i$ Højskolebladet, og denne vilje til at formidle sine resultater og skabe debat fulgte ham siden. I de følgende år var Thyssen undervisningsassistent på Det Teologiske Fakultet, Aarhus Universitet. Disse år var ikke nemme for ham. Thyssen havde stiftet familie, børn kom til, og sammen med sin trofaste hustru og støtte, Eva, måtte han slide for at få det hele til at hænge sammen. Thyssen underviste i næsten alt, med Gammel Testamente som den eneste undtagelse. Lønnen var ikke stor, og i semestrene skulle der spares op til sommerferien. Samtidig lykkedes det ham at afse midler til andre ting: ved et tilfælde blev jeg i 1990'ernes begyndelse klar over, at Thyssens i en årrække havde støttet baltiske grupper efter den russiske magtovertagelse i 1930'ernes slutning, støttet ud fra idealistiske motiver trods en anstrengt privatøkonomi. Det er nok i disse vanskelige år, Thyssens medfødte jernvilje og flid fandt sin form. En vis ensidighed, ja, hensynsløshed og vilje til at sikre sig arbejdsro og tid til de krævende kildestudier var nødvendige hjælpemidler for at kunne fuldføre den store opgave at skrive venstregrundtvigianismens historie i bevægelsens første år. I 
1958 kom så Den nygrundtvigske Bevagelse med sarligt Henblik paa den Borupske Kreds I, et 496 sider stort arbejde, der som al Thyssens senere produktion blev skrevet $\mathrm{i}$ hånden. Værket er en uomgængelig klassiker for den, der vil fordybe sig i den danske kirke- og kulturhistorie i slutningen af det 19. århundrede. Regin Prenter har betegnet værket som et stykke teologisk idehistorie, og man beklager ved læsningen kun, at Thyssen aldrig fik fuldført anden del. Undervejs var der dog kommet en række mindre afhandlinger med belysning af højregrundtvigianismen, og værket satte sig spor i en spændende offentlig debat om den grundtvigske bevægelses resultater, en slags statusopgørelse, hvori så forskellige personligheder som Hal Koch og Jørgen Bukdahl deltog. Thyssen kunne med lethed have fortsat med sine studier i grundtvigianismen, men en nødvendig opgave ventede: udforskningen af det 19. århundredes danske vækkelser.

Flere forhold bevirkede, at dette forskningsprojekt skulle sættes i gang netop i disse år. Da Thyssen indledte sit arbejde med nygrundtvigianismen, var det ikke mange år siden, at den betydelige venstregrundtvigianer Johan Borup i en høj alder var afgået ved døden, og erindringen om de bevægede år fra 1880'erne og frem til efter århundredskiftet levede endnu hos gamle mennesker og deres børn. Men vækkelsernes tidsalder lå mere end 100 år tilbage, og det var nu, man gennem systematiske kildestudier skulle fuldføre den nationale opgave at kortlægge deres tilblivelse og betydning. Samtidig provokerede P. G. Lindhardts materialistiske historieskrivning til en grundig undersøgelse. Var det muligt empirisk at eftervise vækkelsernes sammenhæng med sociale og økonomiske vilkår og forandringer, eller skulle man søge andre forklaringsmodeller?

Thyssen gik til værket sammen med en kreds af yngre medarbejdere, og hans energi og vilje til at føre projekter til ende fejrede her triumfer. Thyssen forfattede egenhændigt omkring halvdelen af værket. Den åbenhed og de hypoteser, der naturligvis fremkommer $i$ hans indledning til serien, blev i det afsluttende binds afrunding afløst af en markant vilje til at sammenfatte resultaterne i en tese og $\mathrm{i}$ den at gøre op med materialistiske, socio-økonomiske forklaringsmodeller. I stedet fortolkede Thyssen vækkelserne idehistorisk i perspektiv af, hvad man i dag ville betegne som den moderniseringsproces, som det danske samfund gennemgik i kraft af pietisme og oplysning i 1700-tallet, vækkelser og nationale bevægelser i 1800-tallet. Myndiggørelsen af det enkelte individ og de valgte fællesskabers brud med landsbykulturens givne sammenhænge fortolkes af Thyssen ud fra begrebet "folkelige bevægelser". Med folkelighedsbegrebet knyttede Thyssen ikke blot til ved Roar 
Skovmand, men også ved N. F. S. Grundtvig, idet han således både fik udtrykt, at Grundtvig skulle ses i sammenhæng med samfundsudviklingen og samtidig var den mest fremtrædende fortolker af en udvikling. Med sin afslutning markerede Thyssen, at han var i stand til at sammenfatte et historisk forløb og pege på fællestrækkene, samtidig med, at han gjorde dette med den forsigtighed, der var så karakteristisk for ham, og trods sin idehistoriske tilgang holdt muligheden for en forbindelse til samfundsudviklingen som helhed åben.

Thyssen er blevet betegnet som positivistisk historiker, og andre har peget på, at han som forsker i højere grad mestrede den omhyggelige indsamling af kildemateriale end udarbejdelsen af de synteser, der gør det muligt at gribe en udvikling og skrive nogle hovedlinjer frem i historien - karakteristikker, der ikke holder vand, men nok kunne fă et skær af sandsynlighed over sig i kraft af Thyssens meget saglige og lidt distancerende form. Samtidig kunne andre af Århusteologerne markere sig $\mathrm{i}$ offentligheden $\mathrm{i}$ kraft af deres evner til at nå ud i medierne med slagkraftige formuleringer. Thyssen levede i høj grad sit liv inden for universitetets rammer, og sammen med den tungtvejende saglige uenighed var det nok medvirkende til at skabe det modsætningsforhold til P. G. Lindhardt, der i de senere år afløste deres oprindelige samarbejde.

Modsætningsforholdet blev paradoksalt nok skærpet af, at Pontoppidan Thyssen i 1970'erne og 1980'erne knyttede tætte kontakter til den marxistisk inspirerede fagkritiske gruppe på Det Teologiske Fakultet. Når Thyssen med sit borgerlige politiske standpunkt og sin uvilje mod materialistisk historièskrivning kunne samarbejde med de unge, var der dog mere end blot strategi med i spillet: uden at han selv ønskede at arbejde med fakultetsledelse, bifaldt han universitetets demokratisering og var en ivrig tilhænger af den selvstændiggørelse af studenterne, der prægede den nye studieordning, og trods sin skepsis over for en for stærk teoretisering fandt han de så udbredte socialisationsteorier spændende. Ligesom flere af de unge var Thyssen kritisk over for den herskende tidehvervsk prægede folkekirketeologi, og han udsendte på den baggrund en lille bog, Den danske folkekirkes struktur fra 1979, hvori han med lidenskab tog del i debatten og med Grundtvigs udviklingsbegreb i ryggen og ud fra sin forsknings positive begreb om folkekirken som det myndiggjorte folks kirke kritiserede, hvad han opfattede som en stivnet og forstenet statskirkelighed. Endelig var de fagkritiske kirkehistorikere ligesom mange i deres generation optaget af de folkelige bevægelser og havde derigennem et positivt forhold til Grundtvig og den grundtvigske tradition. Hen imod slutningen af den marxistiske æra på universitetet faldt Grundtvigs 200 års fødselsdag, og Thyssen benyttede anledningen til sammen med 
Chr. Thodberg at samle en række forskere om den opgave at skrive en moderne dansk og international videnskabelig indføring i Grundtvigs forfatterskab og virke. Dette initiativ er baggrunden for, at Thyssen sammen med Chr. Thodberg og J. H. Schjørring i 1989 grundlagde Center for Grundtvigstudier på Det Teologiske Fakultet. Thyssen blev i disse år kaldet til professor i nyere tids kirkehistorie og havde nu en position, der stod i det rette forhold til hans forskningsindsats.

Parallelt med vækkelsesstudierne havde Thyssen taget den egentlige Grundtvig-forskning op. Allerede bogen om nygrundtvigianismen rummer en grundig redegørelse for Grundtvigs folkelighedsbegreb, og Thyssen var officiel opponent, da Kaj Thaning i 1963 forsvarede sin doktorafhandling med den markante tese om Grundtvigs selvopgør i 1832. Thyssens opposition var skarp, og samtidig ydede han værket en vis anerkendelse. Thanings Grønbech-inspirerede fremhævelse af Grundtvigs omvendelse til livet og hans betoning af Grundtvigs adskillelse af kristendom og menneskeliv æggede Thyssen til modsigelse. Hvor Thaning ønskede at bringe Grundtvig på afstand af pietismen, betonede Thyssen forbindelserne i sin afhandling om Grundtvig og Spener i Grundtvig-Studier 1965, en studie, hvori han pegede på forskelle, men ikke mindst ligheder mellem Grundtvig og den tyske pietist. Ved Grundtvig-jubilæet i 1983 kom så det føromtalte samleværk Grundtvig og grundtvigianismen $i$ nyt lys. Værket blev til i samarbejde med Det danske Selskab, i dag Det Danske Kulturinstitut, og var af Thyssen tænkt som den moderne introduktion til forskere og folkeoplysere i Danmark og udlandet. I forhold til folkeoplysningen i Danmark og ikke mindst i udlandet har værket næppe fungeret efter hensigten, dertil er bidragene for tunge, og som antologi er værket uden den markante linje, der har gjort Thanings og Poul Dams bøger læste over hele verden med en virkningshistorie, der endnu ikke er afsluttet. I dansk og international forskning gjorde bogen imidlertid sin virkning. Det var Thyssens mål at udarbejde et alternativ til Thanings adskillelsestese, og med dramatisk sans lagde han det seminar, hvor bidragene blev præsenteret, på den af Thaning grundlagte Båring højskole. I værket nævnes Thaning ikke med navn, men Thyssen skrev selv tre store kapitler om udviklingen i Grundtvigs tænkning, samlet under overskriften Grundtvigs tanker om kirke og folk, og heri peger han på, hvorledes Grundtvigs evne til at reagere på og leve med i sin samtid gør det vanskeligt at fastholde en tese om en udviklingslinje frem mod et vendepunkt og brud i forfatterskabet, således som Thaning gjorde det. Alligevel yder Thyssen fortsat Thaning en betinget anerkendelse, idet han indrømmer, at Grundtvig i 1830'erne tilkender menneskelivet en vis begrænset selvstændighed $i$ forhold til 
kristendommen, om end han forlægger dette standpunkt til slutningen af tiåret. I 1832 er Grundtvig ifølge Thyssen præget af en svingning mellem en positiv og negativ holdning til sin samtid, men i 1837 afløses dette af en optimisme og vilje til samarbejde med mennesker med et andet udgangspunkt.

I de følgende år var det imidlertid opfattelsen af Grundtvigs forfatterskab som præget af hans skiftende reaktioner på tiden, der blev dominerende $i$ Thyssens forskning. Thyssen sad livet igennem i en lang række bedømmelsesudvalg, foruden Thanings også udvalget $\mathrm{i}$ forbindelse med Erik Heinemeiers licentiatafhandling om Grundtvigs menneskesyn og udvalg i forbindelse med både teologiske og humanistiske doktorafhandlinger. Thyssen var almindeligt anerkendt som den førende ekspert i kirkehistorien fra det 18. århundrede og frem, og hans bevidsthed om kirkens forhold til samfundet gjorde det naturligt at lade ham være medbedømmer på eksempelvis $\mathrm{H}$. C. Hansens afhandling om den grundtvigske naturvidenskabsmand la Cour og Henrik Ydes værk om det grundtvigske i Andersen Nexøs forfatterskab. Han var med til at opfordre Helge Grell til at indlevere sine arbejder til forsvar for doktorgraden ved Det Teologiske Fakultet i Århus, og han kunne bifalde Grells forsigtige tolkning af Grundtvigs tanker om folk og folkelighed i hovedværket Skaberånd og folkeånd fra 1988 - ikke mindst fordi Grell heri vendte sig kritisk mod Thanings tese. Han forholdt sig meget kritisk til Bent Christensens afhandling Omkring Grundtvigs vidskab fra 1998 på grund af Bent Christensens Thaning-inspirerede arbejde med udviklingslinjer i forfatterskabet. I sin opposition, trykt i Grundtvig-Studier 1999, rendyrker Thyssen sin opfattelse af den manglende kontinuitet i Grundtvigs forfatterskab, rendyrker $i$ en sådan grad, at man som kender af forfatterskabet nødvendigvis må reagere.

Bent Christensens bedømmelsesudvalg blev det sidste, der fik glæde af Thyssens arbejdskraft. På grund af sygdom var det ikke muligt for Thyssen at indgå i arbejdet med Ole Vinds afhandling, hvor han blev erstattet af Gunhild Nissen. Thyssen nåede dog i disse år at publicere et 50 sider langt forarbejde til en monografi om Grundtvig og Sønderjylland, og få år forinden havde han i Dansk Kirketidende givet en fremragende fremstilling af skiftene i Grundtvigs kirkesyn. Baggrunden for Sønderjyllandsstudierne var blandt andet hans fuldførelse af Nedergaards danske præste- og sognehistorie med bindet om Haderslev stift. Thyssen havde i sin bevidsthed et fuldstændigt, detaljeret kort over den kirkelige og nationale geografi i Sønderjylland, og han havde fat $\mathrm{i}$ et spændende og temmelig uudforsket stof $\mathrm{i}$ forbindelse med Grundtvigs politiske virke i tiden mellem de slesvigske krige. 
På grund af sygdom blev værket imidlertid aldrig fuldført, og efter en række år med alderdomssvækkelse fik Thyssen fred i foråret 2004.

I disse år, hvor Grundtvig og det grundtvigske er i modvind i den danske offentlighed, savner man hans saglighed, indlevelse - og engagement $-i$ debat og forskning. Samtidig har Thyssens arbejder et efterliv: de fremstår som uomgængelige standardværker og vil gøre deres virkning i mange år frem i tiden. 